\title{
Potato sprout inhibition and tuber quality after post-harvest treatment with rosemary (rosmarinus officinalis I.) leaves and branches
}

\begin{abstract}
Storage of potatoes is one of the most important concerns in maintaining freshness and nutritional quality in the storage process. To achieve this, an experiment was carried out with five different storage conditions at various temperatures using fresh rosemary leaves and branches with three replicates. The results revealed that storage of potatoes at $25^{\circ} \mathrm{C}$ with rosemary leaves and branches resulted in the lowest sprout development and weight loss after 10 weeks. This was significantly different from either $4^{\circ} \mathrm{C}$ or $30^{\circ} \mathrm{C}$. The findings indicated the potential of rosemary fresh leaves and branches to improve potato storage life considering its simplicity and efficacy in decreasing the storage cost, the weight loss and sprouting without causing any environmental toxicity. In addition, the potential of rosemary could be used to other fruits and vegetables to investigate further the possible role of rosemary application to prevent fungal rot.
\end{abstract}

Keywords: potato, rosmarinus officinalis, sprouting, storage life, temperature
Volume I Issue I - 2017

\author{
Daryush Talei,' Fatemeh Bina, ${ }^{2}$ Alireza \\ Valdiani, ${ }^{3}$ Abdolamir Bostani ${ }^{4}$ \\ 'Medicinal Plants Research Center, Shahed University, Iran \\ 2Department of Horticulture, Shahed University, Iran \\ ${ }^{3}$ Department of Geosciences and Natural Resource \\ Management, University of Copenhagen, Denmark \\ ${ }^{4}$ Department of Soil Science, Shahed University, Iran
}

Correspondence: Daryush Talei, Medicinal Plants Research

Center, Shahed University, Tehran 3319| I865I, Iran, Tel

+982151213196, Fax +982151213600,

Email d.taleil348@gmail.com

Received: August 27, 2017| Published: September 25, 2017

\section{Introduction}

After rice and wheat, Potato (Solanum tuberosum L.) is the third most important food crop worldwide and provides high quality nutrition, especially food energy, vitamin $\mathrm{C}$, potassium, protein and dietary fiber. ${ }^{1,2}$ Due to their short production cycle, potatoes provide food faster than cereals or legumes and produce more food calories per hectare, and use less water as compared to either wheat or rice. ${ }^{3,4}$ Storage conditions are an important issue in increasing the storage life and conservation of horticultural products such as potatoes. ${ }^{5}$ To assure high quality tubers after storage, it is necessary to begin with healthy, well-matured tubers of an appropriate cultivar for the intended purpose. However, several factors influence the final quality of potato tubers. These include duration of storage, dormancy status and physiological age, diseases and pests, temperature, relative humidity, application of postharvest chemicals and the composition of the atmosphere surrounding the stored tubers. ${ }^{6-8}$ Although fruits and vegetables are often treated with fungicides to delay postharvest disease, due to the adverse effects of chemicals on human life and environmental pollution, their application in the storage process is limited..$^{9,10}$ Application of non-chemical methods, such as the use of gamma rays, UV light, heat therapyand natural products have been developed in the management of postharvest fungal rotting of fruits and vegetables in recent years. ${ }^{5,9,11,12}$ Rosemary (Rosmarinus officinalis L.) is a spice and medicinal herb widely used around the world.

It is mainly produced in Italy, Dalmatia, Spain, Greece, Turkey, Egypt, France, Portugal and North Africa. ${ }^{13}$ Rosemary leaves are used in foodstuffs, especially for the control of microbial infections. ${ }^{14,15}$ The leaves are also reported as an antioxidant due to the presence of rosmarinic acid, carnosol, carnosic acid and caffeic acid. ${ }^{16,17}$ Among natural antioxidants, rosemary has been widely accepted as one of the spices with the highest antioxidant activity. ${ }^{18,19}$ The essential oil of rosemary has been reported as a tonic stimulant and it is used as a pulmonary antiseptic, a choleretic, and a colagoguic, and also shows stomachic, antidiarrhoeal and antirheumatic properties. ${ }^{20}$ Recently, the exploitation of natural products to control decay and prolong storage life of perishables has received more and more attention. ${ }^{21}$ Rosemary has antimicrobial properties and can be important in reducing postharvest losses. The essential oils play a role in plant defense mechanisms against micro-organisms. ${ }^{22}$ Investigation on the mode of action and practical applicability of such plant products is required to recommend their formulation in control of postharvest diseases. ${ }^{21}$ With a broad range of natural fungicidal plant volatiles, numerous opportunities exist to explore their usefulness in controlling postharvest diseases. In the current study, we report how fresh rosemary leaves and branches enhance the storage life of potato (Solanum tuberosum L.).

\section{Materials and methods}

\section{Plant material}

Similar sized and shaped potatoes were provided from the Seed and Plant Improvement Institute, Karaj, Iran. The fresh leaves and branches of Rosmarinus officinalis were collected from the experimental field of the Medicinal Plants Research Center, Shahed University, Tehran, Iran.

\section{Experimental technique}

The experiment was conducted in the Department of Horticulture, Agriculture Science Faculty, Shahed University, Tehran, Iran, during August to November 2012. We carried out an experiment based on a randomized complete block design (RCBD) with five different storage conditions at various temperatures with and without using fresh rosemary leaves and branches, with three replicates. The storage conditions were; $4^{\circ} \mathrm{C}$ in a seed storage apparatus, 25 and $30^{\circ} \mathrm{C}$ without rosemary leaves and branches, and 25 and $30^{\circ} \mathrm{C}$ with rosemary leaves and branches in a controlled incubator. Five hundred grams of the similar sized and shaped potatoes were placed into each paper bag 
(total 15 bags), separately. The three bags of potato samples (control samples) were located in the seed storage apparatus at $4^{\circ} \mathrm{C}$, three bags at $25^{\circ} \mathrm{C}$ and three bags at $30^{\circ} \mathrm{C}$ in the controlled incubator, separately. One hundred and twenty grams of rosemary leaves and branches were put inside the each paper bag (total six bags) between the potatoes. Three bags were maintained in the controlled incubator at $25^{\circ} \mathrm{C}$ and three bags at $30^{\circ} \mathrm{C}$, separately. After one week, the weight loss (WL) and sprouting of potatoes was measured every week for 10 weeks of the experimental period.

\section{Statistical analyses}

The analysis of variance (ANOVA, one-way analysis) was performed using SPSS software version 22 to detect the significance of differences among the treatment and the means were compared using the Duncan's multiple range test at the $1 \%$ probability level. The Graph Pad Prism software No. 6 was used for drawing the graphs.

\section{Results}

The analysis of variance showed that different storage conditions affected the weight loss and average bud length (ABL) of potatoes. Variation due to storage conditions (SC) in terms of the weight loss and average bud length was significant during the experimental period $(\mathrm{P} \leq 0.01)$ (Tables $1 \& 2)$. The highest weight loss $(64.7 \mathrm{~g})$ were observed at $30^{\circ} \mathrm{C}$ storage conditions without rosemary leaves and branches after 10 weeks of storage time, whereas the lowest $(23.3 \mathrm{~g})$ occurred at $25^{\circ} \mathrm{C}$ storage conditions with rosemary leaves and branches (Figure 1). In the first week, potato weight loss started; in the second week a considerable weight loss was observed. The highest sprouting (the average bud length) $(4.1 \mathrm{~cm})$ were observed at $30^{\circ} \mathrm{C}$ storage conditions without rosemary leaves and branches after 10 weeks of storage time, whereas the lowest $(1.9 \mathrm{~cm})$ occurred at 25 and $30^{\circ} \mathrm{C}$ storage conditions with rosemary leaves and branches (Figure 1). In the third week, potato buds started to appear. The results indicated that there were high significant differences among storage times on the $\mathrm{WL}$ and the $\mathrm{ABL}$ of potatoes. The mean $\mathrm{WL}$ over the storage conditions varied from 14.6 to $37.5 \mathrm{~g}$ in $25^{\circ} \mathrm{C}$ using rosemary leaves and branches and without using rosemary leaves and branches, respectively. Among the storage conditions after 10 weeks, $25^{\circ} \mathrm{C}$ with rosemary leaves and branches showed the lowest decrease in the $\mathrm{WL}(23.3 \mathrm{~g})$ followed by $4^{\circ} \mathrm{C}(25.7 \mathrm{~g}), 30^{\circ} \mathrm{C}$ with rosemary $(26.0 \mathrm{~g})$, $30^{\circ} \mathrm{C}$ without rosemary $(62.0 \mathrm{~g})$ and $25^{\circ} \mathrm{C}$ without rosemary $(64.7 \mathrm{~g})$. Whereas among the storage conditions at the same condition, 25 and $30^{\circ} \mathrm{C}$ with rosemary showed the lowest ABL $(1.9 \mathrm{~cm})$ followed by $4^{\circ} \mathrm{C}$ $(2.8 \mathrm{~cm}), 25^{\circ} \mathrm{C}$ without rosemary $(3.3 \mathrm{~cm})$ and $30^{\circ} \mathrm{C}$ without rosemary $(4.1 \mathrm{~cm})$. Overall, $25^{\circ} \mathrm{C}$ using rosemary leaves and branches was the best condition with respect to the LW and the ABL (Figure 2).

Table I Mean comparison of weight loss of potato in different storage conditions (Mean values \pm S.E)

\begin{tabular}{llllllllll}
\hline SC & WL2 & WL3 & WL4 & WL5 & WL6 & WL7 & WL8 & WL9 & WL10 \\
\hline 1 & $2.3 \pm 0.3 \mathrm{c}$ & $10.0 \pm 2.0 \mathrm{c}$ & $11.0 \pm 1.5 \mathrm{c}$ & $14.3 \pm 0.7 \mathrm{~b}$ & $16.7 \pm 0.3 \mathrm{~b}$ & $18.3 \pm 0.7 \mathrm{~b}$ & $21.7 \pm 1.3 \mathrm{c}$ & $24.3 \pm 1.7 \mathrm{~b}$ & $25.7 \pm 1.3 \mathrm{~b}$ \\
2 & $16.7 \pm 3.3 \mathrm{a}$ & $25.3 \pm 2.7 \mathrm{a}$ & $32.7 \pm 2.7 \mathrm{a}$ & $36.0 \pm 4.0 \mathrm{a}$ & $44.7 \pm 3.7 \mathrm{a}$ & $47.7 \pm 3.7 \mathrm{a}$ & $52.0 \pm 3.0 \mathrm{~b}$ & $58.0 \pm 1.0 \mathrm{a}$ & $62.0 \pm 0.0 \mathrm{a}$ \\
3 & $10.3 \pm 0.7 \mathrm{~b}$ & $18.3 \pm 0.7 \mathrm{~b}$ & $25.3 \pm 1.3 \mathrm{~b}$ & $31.3 \pm 0.7 \mathrm{a}$ & $42.0 \pm 4.0 \mathrm{a}$ & $51.7 \pm 2.7 \mathrm{a}$ & $58.7 \pm 2.7 \mathrm{a}$ & $62.0 \pm 4.0 \mathrm{a}$ & $64.7 \pm 3.7 \mathrm{a}$ \\
4 & $4.7 \pm 1.3 \mathrm{c}$ & $10.0 \pm 2.0 \mathrm{c}$ & $13.3 \pm 2.2 \mathrm{c}$ & $14.3 \pm 2.2 \mathrm{~b}$ & $16.7 \pm 2.1 \mathrm{~b}$ & $20.3 \pm 2.2 \mathrm{~b}$ & $21.3 \pm 2.2 \mathrm{c}$ & $22.3 \pm 2.2 \mathrm{~b}$ & $23.3 \pm 2.2 \mathrm{~b}$ \\
5 & $4.3 \pm 0.7 \mathrm{c}$ & $10.0 \pm 1.0 \mathrm{c}$ & $14.7 \pm 0.3 \mathrm{c}$ & $16.0 \pm 1.0 \mathrm{~b}$ & $18.0 \pm 0.0 \mathrm{~b}$ & $20.7 \pm 1.4 \mathrm{~b}$ & $23.7 \pm 1.4 \mathrm{c}$ & $25.0 \pm 1.1 \mathrm{~b}$ & $26.0 \pm 1.1 \mathrm{~b}$
\end{tabular}

Different letters indicate significant differences between the values of pairs of treatments within columns at $\mathrm{p} \leq 0.01$. The storage conditions (SC) were: $\mathrm{TI} ; 4^{\circ} \mathrm{C}$ in the seed storage apparatus, $\mathrm{T} 2 ; 25^{\circ} \mathrm{C}$ and $\mathrm{T} 3: 30^{\circ} \mathrm{C}$ without rosemary leave and branches, $\mathrm{T} 4 ; 25^{\circ} \mathrm{C}$ and $\mathrm{T} 5 ; 30^{\circ} \mathrm{C}$ with rosemary leave and braches in the controlled incubator.

Table 2 Mean comparison of bud length of potato in different storage conditions (Mean values \pm S.E)

\begin{tabular}{lllllllll}
\hline SC & ABL3 & ABL4 & ABL5 & ABL6 & ABL7 & ABL8 & ABL9 & ABLI0 \\
\hline $\mathrm{I}$ & $0.3 \pm 0.3 \mathrm{c}$ & $0.3 \pm 0.3 \mathrm{~b}$ & $0.4 \pm 0.4 \mathrm{~b}$ & $1.2 \pm 0.2 \mathrm{~b}$ & $1.9 \pm 0.4 \mathrm{~b}$ & $2.3 \pm 0.3 \mathrm{bc}$ & $2.5 \pm 0.3 \mathrm{bc}$ & $2.8 \pm 0.4 \mathrm{bc}$ \\
2 & $1.2 \pm 0.2 \mathrm{~b}$ & $2.0 \pm 0.1 \mathrm{a}$ & $2.3 \pm 0.1 \mathrm{a}$ & $2.4 \pm 0.0 \mathrm{a}$ & $2.7 \pm 0.1 \mathrm{a}$ & $2.9 \pm 0.1 \mathrm{~b}$ & $3.1 \pm 0.2 \mathrm{ab}$ & $3.3 \pm 0.2 \mathrm{ab}$ \\
3 & $2.1 \pm 0.0 \mathrm{a}$ & $2.6 \pm 0.2 \mathrm{a}$ & $2.8 \pm 0.1 \mathrm{a}$ & $3.0 \pm 0.1 \mathrm{a}$ & $3.3 \pm 0.1 \mathrm{a}$ & $3.6 \pm 0.2 \mathrm{a}$ & $3.8 \pm 0.2 \mathrm{a}$ & $4.1 \pm 0.3 \mathrm{a}$ \\
4 & $0.0 \pm 0.0 \mathrm{c}$ & $0.0 \pm 0.0 \mathrm{~b}$ & $0.0 \pm 0.0 \mathrm{~b}$ & $0.7 \pm 0.3 \mathrm{~b}$ & $1.3 \pm 0.2 \mathrm{bc}$ & $1.7 \pm 0.1 \mathrm{c}$ & $1.8 \pm 0.1 \mathrm{c}$ & $1.9 \pm 0.2 \mathrm{c}$ \\
5 & $0.0 \pm 0.0 \mathrm{c}$ & $0.0 \pm 0.0 \mathrm{~b}$ & $0.0 \pm 0.0 \mathrm{~b}$ & $0.7 \pm 0.3 \mathrm{~b}$ & $1.1 \pm 0.1 \mathrm{c}$ & $1.7 \pm 0.3 \mathrm{c}$ & $1.8 \pm 0.3 \mathrm{c}$ & $1.9 \pm 0.3 \mathrm{c}$ \\
\hline
\end{tabular}

Different letters indicate significant differences between the values of pairs of treatments within columns at $\mathrm{p} \leq 0.0 \mathrm{I}$. The storage conditions (SC) were: $\mathrm{TI} ; 4^{\circ} \mathrm{C}$ in the seed storage apparatus, $\mathrm{T} 2 ; 25^{\circ} \mathrm{C}$ and $\mathrm{T} 3: 30^{\circ} \mathrm{C}$ without rosemary leave and branches, $\mathrm{T} 4 ; 25^{\circ} \mathrm{C}$ and $\mathrm{T} 5 ; 30^{\circ} \mathrm{C}$ with rosemary leave and braches in the controlled incubator.

The slope of the weight loss at $25^{\circ} \mathrm{C}$ using rosemary showed 2.51 g decrease per storage time (one week) followed by $30^{\circ} \mathrm{C}$ with using rosemary, 4,25 and $30^{\circ} \mathrm{C}$ without using rosemary leave and branches. The slope of the average bud length at $30^{\circ} \mathrm{C}$ using rosemary showed $0.26 \mathrm{~cm}$ increase per storage time (one week) followed by $25^{\circ} \mathrm{C}$ using rosemary, 4,25 and $30^{\circ} \mathrm{C}$ without using rosemary leaves and branches (Figure 2). This might be due to the effect of storage conditions during the experimental period. As shown in Figure 2, after 10 weeks, the highest and lowest decrease in WL was observed at $25^{\circ} \mathrm{C}$ without using rosemary leaves and branches, and $25^{\circ} \mathrm{C}$ using rosemary leaves and branches, respectively. Interestingly, the amount of decrease in $25^{\circ} \mathrm{C}$ using rosemary leaves and branches condition was lower that of the normal storage condition $\left(4^{\circ} \mathrm{C}\right)$ (Figure 2$)$. In addition, application of rosemary leaves and branches at 25 and $30^{\circ} \mathrm{C}$ significantly decreased the ABL after 10 weeks of storage time (Figure 2). 

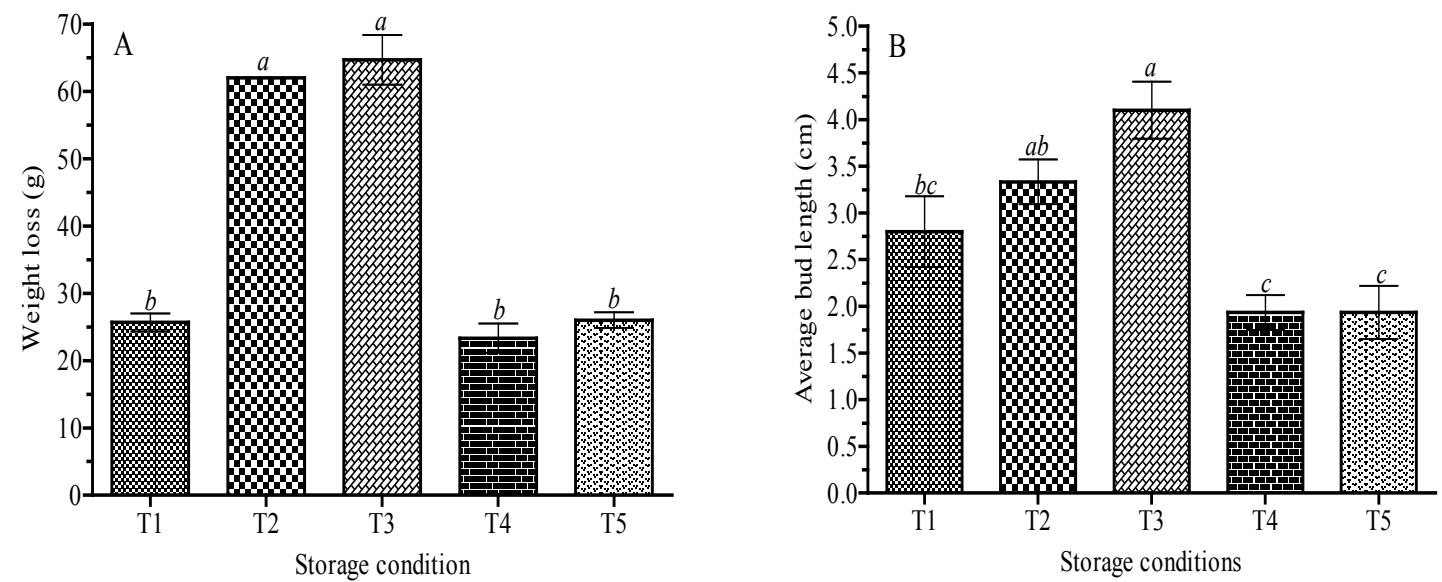

Figure I The effects of storage conditions on the weight loss (A) and the average bud length (B) of potato after ten weeks using Duncan's multiple range test $(\mathrm{P} \leq 0.0 \mathrm{I})$. Different letters indicate significant difference between the values of pair of treatments. Vertical bars represent $\mathrm{SEM}$. for three samples. TI; $4^{\circ} \mathrm{C}$ in the seed storage apparatus, $\mathrm{T} 2 ; 25^{\circ} \mathrm{C}$ and $\mathrm{T} 3: 30^{\circ} \mathrm{C}$ without rosemary leave and branches, $\mathrm{T} 4 ; 25^{\circ} \mathrm{C}$ and $\mathrm{T} 5 ; 30^{\circ} \mathrm{C}$ with rosemary leave and braches in the controlled incubator
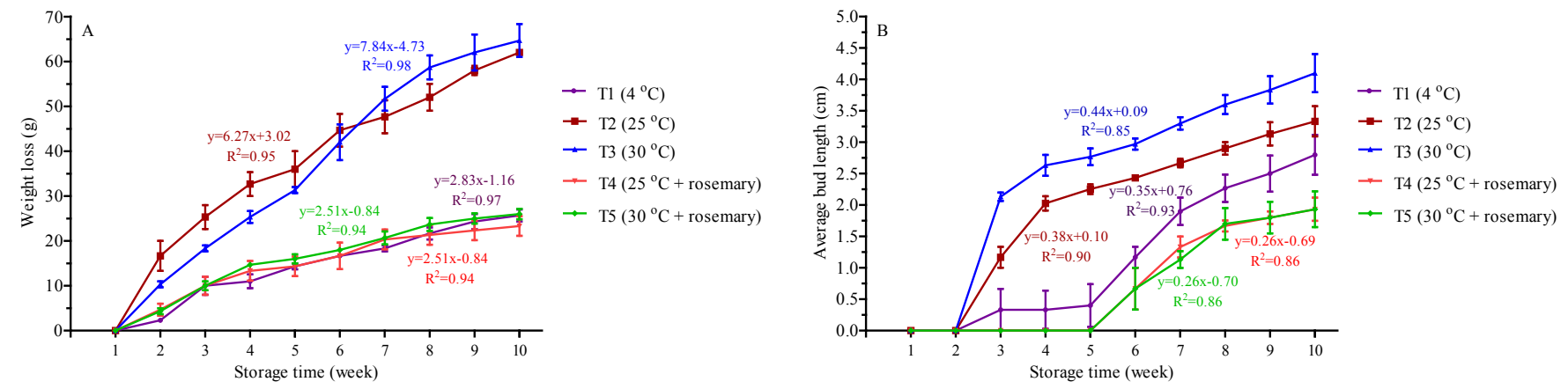

Figure 2 The effects of storage conditions on the weight loss (a) and the average bud length (b) of potato during experimental period ( 10 weeks).Applying the Rosemary leaves and branches at $25^{\circ} \mathrm{C}$ storage conditions showed lowest the $\mathrm{WL}$ and the $\mathrm{ABL}$.

\section{Discussion}

Storage of potatoes is one of the most important concerns in maintaining nutritional quality. Hence, any treatment, such as natural products that control and extend the storage life of potatoes, could be beneficial. In order to investigate the storage life of potatoes, a set of critical post-harvest related indices such as weight loss and sprouting of potatoes were evaluated under different storage conditions. Since refrigerated storage controls the respiration rate of harvested crop products, it delays the following causes of deterioration of crops including: aging due to ripening, softening, color changes, undesirable metabolic changes, respiratory heat production, moisture loss, wilting and spoilage due to invasion by bacteria, fungi, and yeasts. ${ }^{23}$ Application of some natural products such as flavor compounds, acetic acid, jasmonates, glucosinolates, propolis, fusapyrone and deoxyfusapyrone, chitosan and essential oils for the management of fungal rotting of fruits and vegetables has been developed. ${ }^{21}$ Although the exploitation of natural products to protect the postharvest decay of perishable products is in its infancy, these products have the potential to be safe fungicides and could replace the synthetic ones. ${ }^{21}$ Our results revealed the importance of rosemary in improving the storage time by decreasing weight loss.

In a study on the essential oils of ten plants, ${ }^{21}$ recommended that the essential oils could be a potential source of eco-friendly botanical fungicide, after long term and wide ranging trials to exhibit absolute fungi toxic activity up to $100 \%$ growth inhibition. Bina et $\mathrm{al}^{24}$ reported that the application of rosemary fresh leaves and branches can improved the storage life of onions considering its simplicity and efficacy in decreasing the storage cost, the weight loss and sprouting without causing any environmental toxicity. Therefore, applying rosemary leaves and branches to reduce germination and potato weight, the fungal infection and decay is the most effective approach as compared to the recommended chemical sorirradiation storage in potato bulbs. Our results indicated that sprouting (the average bud length) of all treatments except the rosemary treatment increased at temperatures above $4^{\circ} \mathrm{C}$. Variation due to storage conditions was significant in terms of sprouting, average bud length; number of active buds and tuber weight. In agreement with the reports of Struik \& Van Ittersum et al., 25,26 the findings of this study indicated that high temperature decreased the storage time and increased the weight loss and the average length of sprouts, while high temperature along with applying rosemary leaves and branches increased storage time, and under these conditions, the weight loss and sprouting of potatoes were the lowest.

Our results revealed that the potato bulbs had no germination during the first two weeks but by increasing storage time potatoes started to germinate and therefore, the average bud length increased, which matched up with findings of Hartmans et al. ${ }^{27}$ who reported that with increasing storage temperature, the average bud length and number of sprouting of potato tubers were increased. The use of 
herbal ingredients and essential oils in proper sensory tests is needed before making any recommendations. Maintaining the benefits of the plants as fungi toxicants which are effective on postharvest phases should be confirmed properly during accurate laboratory tests and the tests based in vivo experiments, while considering safety measures and applying the most important features. ${ }^{28}$ In order to make better use of rosemary and other herbs in postharvest storage of horticultural crops, it is recommended to complete the investigation of other forms of application, such as the use of essential oils or spraying to foliar tissue, and measure their effect on quality parameters such as taste and flavor of fruits and vegetables. As a final conclusion considering weight loss and sprouting (the average bud length) traits related to postharvest fruits and vegetables, the application of fresh rosemary leaves and branches can be considered as an alternative strategy to control postharvest fungal rotting of fruits and vegetables to improve the storage life of potatoes considering its simplicity and efficacy in decreasing the storage cost, weight loss and sprouting without causing any environmental toxicity. Therefore, the suggested approach can be applied to other postharvest fruits and vegetables for improving the storage life.

\section{Acknowledgements}

This project was supported by Medicinal Plants Research Center, Shahed University, Tehran, Iran.

\section{Conflict of interest}

The author declares no conflict of interest.

\section{References}

1. CIP Facts and figures about potato. International Potato Centre. 2010.

2. Li XQ, Scanlon MG, Liu Q, et al. Processing and value addition. In: Gopal J, editor. Handbook of Potato Production, Improvement, and Postharvest Management. Food Products Press Haworth Press, USA 2006. p. 523-555.

3. Horton D, Sawyer RL. The potato as a world food crop, with special reference to developing areas. Potato Physiology Academic Press Inc Ltd, UK; 1985. p. 1-34.

4. Facts and figures. International Potato Centre. 2013.

5. Nazir AM, Curell E, Khan N, et al. Harvest maturity, storage temperature, and 1-MCP application frequency alter firmness retention and chlorophyll fluorescence of Red chief Delicious' apples. J Amer Soc Hort Sci. 2001;126(5):618-624.

6. Isherwood FA. Starch-sugar inter conversion in Solanum tuberosum. Phytochemistry. 1973;12(11):2579-2591.

7. Mazza G, Hung J, Dench MJ. Processing/nutritional quality changes in potato tubers during growth and long term storage. Canadian Institute of Food Science and Technology Journal. 1983;16(1):39-44.

8. Prange RK, Kalt W, Daniels Lake BJ, et al. Using Ethylene as a Sprout Control Agent in Stored Russet Burbank' Potatoes. J Amer Soc Hort Sci. 1998;123(3):463-469.

9. Sargent SA, Stoffella PJ, Maynard DN. Harvest date affects yield and postharvest quality of non dried, short-day onions. Hortscience. 2001;36(1):112-115.

10. Unnikrishnan V, Nath B. Hazardous chemicals in foods. Indian Journal of Dairy and Biosciences. 2000;11:155-158.
11. Afek U, Kays SJ. Postharvest physiology and storage of widely used root and tuber crops. Hort Rev. 2004;30:253-316.

12. Khodadadi M, Zolfagharyeh HR. The Effects of Electron Irradiation Doses on Storability of Iranian Onion Cultivars. Journal of Nuclear Science and Technology. 2009;3(49):66-72.

13. Atti Santos AC, Rossato M, Pauletti GF, et al. Physico-chemical evaluation of Rosmarinus officinalis L. essential oils. Brazilian Archives of Biology and Technology. 2005;48(6):1035-1039.

14. Lawrence BM. Progress in essential oils. Perfumer \& flavorist. 2000;25(4):55-70

15. Rasooli I, Fakoor MH, Yadegarinia D, et al. Antimycotoxigenic characteristics of Rosmarinus officinalis and Trachyspermum copticum L. essential oils. Int J Food Microbiol. 2008;122(1):135-139.

16. Hraš AR, Hadolin M, Knez Ž, et al. Comparison of anti oxidative and synergistic effects of rosemary extract with $\alpha$-tocopherol, ascorbyl palmitate and citric acid in sunflower oil. Food Chemistry. 2000;71(2):229-233

17. Lindberg MH, Bertelsen G. Spices as antioxidants. Trends in Food Science \& Technology. 1995;6(8):271-277.

18. Peng Y, Yuan J, Liu F, et al. Determination of active components in rosemary by capillary electrophoresis with electrochemical detection. Journal of pharmaceutical and biomedical analysis. 2005;39(3):431437

19. Ramírez P, Señoráns FJ, Ibanez E, et al. Separation of rosemary antioxidant compounds by supercritical fluid chromatography on coated packed capillary columns. Journal of Chromatography A. 2004;1057(1):241-245

20. Pintore G, Usai M, Bradesi P, et al. Chemical composition and antimicrobial activity of Rosmarinus officinalis L. oils from Sardinia and Corsica. Flavour and Fragrance Journal. 2002;17(1):15-19.

21. Tripathi P, Dubey NK, Shukla AK. Use of some essential oils as postharvest botanical fungicides in the management of grey mould of grapes caused by Botrytis cinerea. World Journal of Microbiology and Biotechnology. 2008;24(1):39-46.

22. Mihaliak CA, Gershenzon J, Croteau R. Lack of rapid monoterpene turnover in rooted plants: implications for theories of plant chemical defense. Oecologia. 1991;87(3):373-376.

23. Hardenburg RE, Watada AE. The commercial storage of fruits, vegetables, and florist and nursery stocks. Agriculture Handbook, Washington. United States Department of Agriculture, Agricultural Research Service, USA; 1990. p. 1-792.

24. Bina F, Bostani A, Talei D. Potential of rosemary (Rosmarinus officinalis L.) leaves and branches to enhance storage life of onion (Allium cepa L.) Horticultura Brasileira. 2016:34(3).

25. Struik PC, Wiersema SG. Seed potato technology. Wageningen Academic Pub, The Netherlands; 1999. p. 1-382.

26. Van Ittersum MK, Scholte K. Shortening dormancy of seed potatoes by storage temperature regimes. Potato Research. 1992;35(4):389-401.

27. Hartmans KJ, Van Loon CD. Effect of physiological age on growth vigour of seed potatoes of two cultivars. I. Influence of storage period and temperature on sprouting characteristics. Potato Research. 1987;30(3):397-410.

28. Tripathi P, Dubey NK. Exploitation of natural products as an alternative strategy to control postharvest fungal rotting of fruit and vegetables. Postharvest biology and Technology. 2004;32(3):235-245. 